\title{
Promises of Non/Living Monsters and Uncontainable Life
}

Marietta Radomska

The self-archived postprint version of this journal article is available at Linköping University Institutional Repository (DiVA):

http:/ / urn.kb.se/ resolve?urn=urn:nbn:se:liu:diva-151857

N.B.: When citing this work, cite the original publication.

Radomska, M., (2018), Promises of Non/ Living Monsters and Uncontainable Life, Somatechnics, 8(2), 215-231. https:// doi.org/ 10.3366/ soma.2018.0252

Original publication available at:

https:// doi.org/ 10.3366/ soma.2018.0252

Copyright: Edinburgh University Press

http:// www.euppublishing.com/ 


\title{
Promises of Non/Living Monsters and Uncontainable Life
}

\section{Marietta Radomska}

\author{
[article published in: Somatechnics, vol. 8 no. 2]
}

\begin{abstract}
:
In the Western cultural imaginaries the monstrous is defined-following Aristotelian categorisations-by its excess, deficiency or displacement of organic matter. These characteristics come to the fore in the field of bioart: a current in contemporary art that involves the use of biological materials (various kinds of soma: cells, tissues, organisms), and scientific procedures, technologies, protocols, and tools. Bioartistic projects and objects not only challenge the conventional ideas of embodiment and bodily boundaries, but also explore the relation between the living and non-living, organic and inorganic, human and nonhuman, as well as various thresholds of the living.

By looking at select bioartworks, this paper argues that the analysed projects offer a different ontology of life. More specifically, they expose life as uncontainable, that is, as a power of differentiation that traverses the divide between the living and non-living, organic and inorganic, human and nonhuman, and, ultimately, life and death. In this way, they draw attention to excess, processuality and multiplicity at the very core of life itself. Thus understood, life always already surpasses preconceived material and conceptual limits.
\end{abstract}

Finally, while taking Deleuzian feminisms and new materialism as its theoretical ground, the paper suggests that such a revision of the ontology of life may mobilise future conceptualisations of ethics that evade the anthropocentric logic dominant in the humanities and social sciences.

Keywords: the non/living; bioart; ethics; ontology of life; Deleuzian feminisms; the monstrous. 


\section{Cultural Imaginaries, Somatechnics and Monstrous Flesh}

Monsters have always formed part of both cultural and scientific imaginaries (cf. Shildrick 2009). They cross boundaries and exceed containment in a metaphorical, conceptual and literal sense. And they seem to particularly flourish at the intersection of the cultural and the scientific realms: the figure of Frankenstein's monster, popular-scientific narratives on organisms exposed to radiation, and the discourse on fish affected by hormones that - together with sewage - end up in lakes and rivers and, subsequently, influence the development of nonhuman organisms, are just a few examples. All these creatures (both the actual organisms and the literary figures) are born through technological and scientific interventions into 'nature.' Popular discourses and narratives define their monstrosity in an Aristotelian way: by pointing at the excess, deficiency or displacement of organic matter (cf. Shildrick 2002).

These characteristics of 'the monstrous' also come to the fore in various descriptions of bioart: a current in contemporary art that involves the use of biological materials (cells, tissues, organisms), and scientific procedures, technologies, protocols, and tools. Among most wellknown (if not iconic) bioartworks are such projects as Genesis (involving genetically modified bacteria) by Eduardo Kac; Nature? (butterflies with genetically-modified wing patterns) by Marta de Menezes; and 'semi-living' sculptures by The Tissue Culture and Art Project (TC\&A). Bioartworks are characterised by vulnerability, intrinsic to all beings, and dependency on technologies that allow these creations to come into being, endure and flourish (modifications of bacteria and butterflies' wings in Kac's and de Menezes' works respectively take place through biotechnological interventions, and TC\&A's 'semi-living' sculptures, made of bioengineered animal tissues and biopolymer materials, require sterile conditions of a bioreactor and constant care in order to survive). In other words, technologies both sustain and discipline organic matter. Bioartworks - as always already intertwined with multiple 
biotechnologies and procedures of care - form part of an assemblage that challenges conventional scientific, biomedical, and cultural imaginaries of embodiment. In the context of bioart, the body (of a 'semi-living' sculpture, for instance) is exposed not as self-contained, sealed, and autonomous, but, instead, as 'leaky' (Shildrick 1997), open, vulnerable, and entangled in a set of relationalities with its 'naturalcultural' (Haraway 2008) environment.

What we observe - when looking at both bioart pieces and practices through which they come into being - are complex mechanisms of somatechnics, where fleshy materialities and technologies are linked to one another through 'chiasmic interdependence ... of bodily being (or corporealities) as always already technologised, and technologies as always already enfleshed' (Sullivan and Murray 2009: 3). As body theorists working with this conceptual framework emphasise, the idea of 'somatechnics' allows for an understanding of the inherent entwinement between 'hard' technologies and 'soft' techniques of power and discourse, on the one hand, and bodies, on the other. While the substantial amount of somatechnical research focuses on how human bodies and bodily substances are intimately entangled with and continuously moulded by diverse norms, mechanisms and practices (for example, Sullivan and Murray 2009), this paper focuses on the ways somatechnics operates below the level of the human body, that is, the level of biological matter as such.

Despite the diversity of themes and foci, most bioartworks explore and concentrate on the question of life: of the thresholds between the living and non-living, and the natural and artificial, as well as the ways that 'tinkering' with organisms and/or their fragments may challenge Western cultural imaginaries of the living and the body. Here I look at one of the most iconic and well-known examples of bioart, Victimless Leather (referred later as ' $V L$ ') by the Tissue Culture and Art Project (TC\&A), first realised in 2004 and subsequently recreated a number of times. By employing a somatechnical lens, that is, a critical and attentive approach to the interweavings of biomatter and technology, this paper argues that bioart exposes life as 
uncontainable: life as always already characterised by a potential for excess. Uncontainability - being one of the key ontological characteristics of life - is what virtually renders life monstrous in the Aristotelian and cultural imaginary terms. It points to such aspects of life processes as uncontrollability, indeterminacy and multiplicity. Furthermore, it reveals the blurring of boundaries between living and dying and growth and decay that lay at the heart of what we call 'life'. Thus, life appears as always already non/living (Radomska 2016), where the slash ('/') refers to the inherent entanglement of these multiple processes, which we commonly associate with the notions of life and death. In the following sections, I will first focus on the project $V L$ and the ways in which the workings of a somatechnical assemblage through which this piece emerges challenge understandings of life and the body pertaining to Western cultural imaginaries. This will bring me to a more detailed reflection on an ontology of life exposed through the hybrid scientifico-artistic practices of bioart. Finally, I will concentrate on how such a rethinking of ontology, where life is always already monstrous: uncontainable and non/living, may mobilise an ethics attentive to the dynamic, multiplicitous difference of the non/living that evades human control and transgresses both conceptual and material boundaries.

\section{Victimless Leather: On Becoming-Monstrous}

TC\&A was founded by Oron Catts and Ionat Zurr in 1996 as 'an ongoing research and development project into the use of tissue technologies as a medium for artistic expression' (TC\&A 2001). It came into being thanks to collaboration with the Department of Anatomy and Human Biology, University of Western Australia (UWA) and SCIETECH Discovery Centre. Since its inception, TC\&A has been interested in the exploration of the relations between organisms and their environment, the living and non-living, the agency of living matter, and the ways in which the relations between entities play a role in the shaping and development of these entities. The artists have gained support from a number of Australian scientific institutions and 
funding bodies, which has helped them to continue and further develop the project. In 2000 Catts and Zurr, accompanied by biologist Miranda Grounds and neuroscientist Stuart Bunt, launched SymbioticA, a scientifico-artistic research laboratory based in the School of Anatomy and Human Biology at UWA. The primary aim of the lab is to "create a space for artists (and other non-biologists) within a biological scientific department to engage in critical research in an experimental way with the manipulation of living systems or parts of living systems' (Zurr and Catts 2003: 9). In their projects, the artists use animal tissue engineering techniques in order to create 'semi-living' sculptures or so-called 'objects of partial life' (consisting of animal tissues grown over biopolymer base). One of TC\&A's aims is to engage with the question of how the employment of semi-living products may affect the risks linked to both new and old technologies, as well as how shifting the mode of production from manufacturing to growing may affect the environmental issues related to the processes of both production and consumerism broadly speaking.

$V L$ (a semi-living sculpture in the shape of a tiny jacket) forms part of the series of works entitled Victimless Utopia. Along with $V L$, the series comprises two other projects: Disembodied Cuisine (exploring the idea of the creation of 'cruelty-free meat'; 2003) and DIY De-victimizer Kit (aimed at 're-life-ing' of animal bodies previously killed through the use of technology; 2006). Victimless Utopia has been conceptualised and designed to deal with the issues of animal consumption (in the form of both meat and leather), commodification and exploitation. It exposes the biopolitical logic described by Cary Wolfe (2012): the ongoing growth of phenomena such as industrial farming, with its severe consequences for nonhuman animals, humans, and the environment, is combined with a technoscientific fascination with the idea of the 'victimless utopia,' a world in which biotechnologies (including tissue engineering) and other scientific developments guarantee the untroubled production of meat and leather without killing nonhuman animals. By employing irony in the creation of supposedly 
'victimless' objects (like tiny 'steaks' grown from frog skeletal muscle tissue in Disembodied Cuisine), TC\&A points out that living in and consuming the world is never victimless. Rather, we should ask ourselves which lives matter, which are recognised as the ones to be valued, and the ones to be mourned.

As TC\&A emphasises, animal tissue culturing requires the use of foetal bovine serum, which is produced from the blood harvested from bovine foetuses that have been removed from the bodies of slaughtered cows. Years after TC\&A's first experiments/projects involving the culturing of animal muscle tissue (that is, in the second decade of 2000s), the idea of 'growing meat' in a laboratory - as a more ethical and environment-friendly alternative - has become an object of scientific investigation and a desirable goal. In 2013 a team of scientists led by physiologist, Mark Post, succeeded in creating the first laboratory-grown burger, the production of which cost $\$ 330,000$ at the time (Maastricht University 2015). Two years later, the price had dropped to $\$ 11$ per burger (Stone 2015). Yet, Mosa Meat (a company launched by Post and linked to Maastricht University), along with other research teams around the world are still working on finding an animal-free alternative to the currently used nutrient: foetal bovine serum. Through their playful and ironic projects, TC\&A demonstrates that the notion of 'victimless-ness' is an illusion. They ask us to look deeper and not just stop at the surface: to reflect on our anthropocentric optics and ethics, our ways of relating to the nonhuman, as well as of attending to and consuming the world that we form part of. ${ }^{1}$

Between November 2009 and February 2010 TC\&A showed $V L$ as part of the exhibition Medicine and Art: Imagining a Future for Life and Love at the Mori Art Museum (MAM). Each time Catts and Zurr exhibit their semi-living artworks, they have to grow the objects anew in a local laboratory, as travelling with the sculptures is impossible due to both technical and legal reasons. The show at MAM was the tenth time TC\&A presented the miniature 'leather jacket' reflecting upon the consumption of animal bodies in the form of leather. The biopolymer 
scaffolding of the artwork prepared for the exhibition in Tokyo took the shape of a kimono. During the very early stages of the exhibition, when the tissue had only just begun to grow over the base, the sculpture became infected with fungi. For ten days following the appearance of the infection, the artists regularly applied antifungal treatment to the artwork. Despite their efforts, the fungi took over, resulting in a flower-shaped excrescence positioned right next to one of the sleeves (The Art Catalyst 2012). Furthermore, as the piece was expected to be alive and in 'good shape' for the three months of the show, local scientists had to re-grow the sculpture twice and care for the tiny kimono on a daily basis (Johung 2014).

Let us now look at the technical aspects of the piece. The tissue of $V L$ has a hybrid character. It is a combination of rodent and human cells: $3 \mathrm{~T} 3$ fibroblast mouse cells and HaCat keratinocyte human cells, ${ }^{2}$ which are seeded onto a synthetic, biodegradable, bio-absorbable, 3D, polymer scaffolding, which is placed in the sterile conditions of a customised bioreactor designed as an organ perfusion pump (mediasanctuary 2014). To reiterate, in this particular project, the polymer base is in the shape of a jacket/kimono. The bioreactor has a special drip system through which the tissue is provided with nutrient solution. It is crucial that an appropriate stable temperature is guaranteed. Along with practical, technical, and historical aspects, the design of the bioreactor in which the sculpture has been grown during each of the shows is also characterised by specific aesthetic features. The spherical shape of the vessel in which the piece is located, combined with the drip system with its exposed glass containers and pipes filled with pink-coloured nutrient medium and accentuated by red lighting, speak to the cultural imaginaries of how science is supposed to look. At the same time, the installation brings to mind science-fiction stories featuring 'mad scientists' and their futuristic bio-experiments that audience members might have read during childhood. The shapes and colours both speak to one's imagination and bring visual pleasure. 
However, the question of sterility in animal tissue culture, emphasised by both bioartists and scientists, is a difficult one. It is not only fungi - the presence of which on the kimono at MAM was easily noticeable with the naked eye - that find their dwelling among growing animal cells. Animal tissue cultures are susceptible to contamination with fungi as well as less detectable organisms, such as bacteria, mycoplasma and viruses (cf. Martin 1994). Hence, the issue of sterility is heavily emphasised in protocols dealing with tissue engineering. As the fungal growth on the jacket was noticed only after it had become completely visible without the employment of any optical devices, and right afterwards the anti-fungal treatment was applied, we do not really know if there were any other actants present in the vessel, especially because for some of them it takes a relatively long period of time for a generation to grow. It was that particular somatechnological setup - the practices of creating and exhibiting bioartworks - that in this case excluded the presence of any other potential living components of the contaminated kimono, while rendering the animal tissue and the fungi meaningful.

During the MAM exhibit the 'contaminant' disturbs the illusion of a neat and valuable, yet living, artwork. The artists frequently mention the Tokyo show as an anecdote to point out the impossibility of exercising complete control over life processes, a fact which, they argue, the popular discourses on science, designers, and biotechnologists frequently fail to recognise (cf. Schwartz 2008). TC\&A wishes their work to disturb and fail: art as a field, in contrast to design, for instance, does not aim to provide solutions, but instead to generate questions, to trouble the audience, and mobilise different ways of thinking and sensing. The fungal excrescence at the Tokyo show is disruptive, matter out of place that should instead be removed, neutralised, and discarded. In other words, that which exceeds 'the norm', which transgresses boundaries and thus appears as 'monstrous', needs to be tamed, captured and disciplined. The problem is that none of these unwelcome appearances can be removed without affecting - or, more precisely, killing - an artwork. Fungi and abundant out-of-control cells, which are perceived by some of 
the curators, commentators and members of the audience as waste, something excessive, or 'invader', illustrate indeterminacy, uncontrollability, and vulnerability as key features of what we deem as 'life'.

Although every possible measure is taken to secure optimum conditions for the growth of the tissue, it is impossible to determine all aspects of its development. There is always a risk that the tissue culture may become infected with microorganisms or grow too fast for the available space and nutrients. These aspects can only be estimated and cannot be fully predicted. Moreover, the semi-living sculpture does not constitute an independent entity attacked by an external enemy: the fungus. In fact, the infected tissue forms an assemblage, which mutates, changes, transforms, and in which the divisions and relations between 'proper tissue' and infecting microorganisms, as well as between processes of growth and decay, are shaped.

The infected/affected tissue also evokes a wider sense of the entanglement between life and waste revealed through somatechnological mechanisms: how that which has been disposed of influences the bodies of both a human and a nonhuman kind; and how the distinction between things and processes that are deemed to be 'life,' and those that are abundant and disposable, becomes blurred. It is common for organic matter initially framed as 'life' to later become categorised as 'waste': this is exactly what happens to the cells, tissues, and organisms used in bioscientific experiments (cf. Mehrabi 2016). Once their flesh has been experimented on and, consequently, is no longer needed for research purposes, it becomes (biohazardous) waste. For living matter to be ascribed a value (the status of life) or a lack thereof (waste) often entails further consequences. In the context of a laboratory, once a fragment of biomatter is discursively and materially transformed into waste, it either requires disposal and neutralisation (that is, killing and incineration, as it happens with the semi-living sculptures once the exhibition is over), or, in some cases, it may be used as a resource in biomedical research or industry (like umbilical cord blood used in regenerative medicine). 
The dichotomy of life and waste may be seen as parallel to Giorgio Agamben's (1998) distinction between bios/zoe and bare life. While zoe in Agamben's writings describes biological existence, 'bare life' refers to life 'Stripped from political significance and exposed to murderous violence' (Ziarek 2012: 194). Agamben's bare life, as Ewa Plonowska Ziarek argues, is 'wounded, expendable, and endangered, [it] is not the same as biological zoe, but rather the remainder of the destroyed political bios' (2012: 195). Life-deemed-waste in a bioscientific laboratory is stripped of its scientific value and significance and, thus, exposed to neutralisation and killing. In a similar way, for Agamben, life deprived of its political value, status, and significance becomes exposed to violence and slaughter. Thus, both life-deemedwaste and bare life hinge on the notion of value. To turn into waste means to lose worth, significance, or purpose.

A somatechnical perspective - attentive to the entwinement of bodily matter and both 'soft' and 'hard' technologies - employed here points to a crucial issue: dealing with life in both bioscience and bioart entails the question of the control and predictability of life, and the possibility of containing it within the prescribed, spatiotemporal frames. Life in bioscientific and bioartistic contexts is closely entwined with the issue of waste. Meanwhile, waste, when classified as biohazardous, links back to the problem of contagion. The case of $V L$ and the TC\&A's show in Tokyo tell a lot about our approach to life and the ways it is premised upon the cultural imaginaries of the monstrous: that which is different, excessive, and transgresses prescribed 'norms' or boundaries is expected to get captured and disciplined (cf. Foucault 2003). While this essay does not attempt to say that bioscientific protocols should be changed or abandoned (that would be both ridiculous and plainly dangerous), it strives to demonstrate how our relations towards things deemed 'living' are interlinked with the cultural notions of the contained body and clear-cut division between 'life' and 'non-life'. Yet, the issues of relationality and affect (ethics) are not independent from what life means at the level of 
ontology. As feminist materialist theorists remind us: ethics, epistemology and ontology are entangled with one another (cf. Barad 2007). In the following section, I will concentrate on the ontology of life enacted and exposed through the hybrid practices of bioart and, in particular, the $V L$ project.

\section{Ontology of the Non/Living}

In order to engage with the ways bioart mobilises a postconventional and somatechnical understanding of the ontology of life, let us first look at the place of the concept of life in the Western tradition of thought.

Already at the very inception of philosophy, the Presocratics speak about psukhe: the basic principle that gives rise to every phenomenon and sustains it. However, philosopher Eugene Thacker (2010) argues, it is Aristotle who is seen as the first key thinker not only to take up the problem of life as an ontological question, but also to establish the frame of this enquiry that will remain present in Western philosophy until modernity. He notes that Aristotle identifies a set of characteristics specific to life (form; movement; immaterial principle). Yet, there is a problem with Aristotle's search for an adequate concept of life. On the one hand, the concept of life should transcend life in its different forms (so that it can explain these forms' dynamism and alteration). On the other, it should be immanent to life so that it may manifest the inseparability between principle and manifestation (Thacker 2010: 11). The problem is of the separation between the concept of life and the living. Aristotle solves this by introducing a reworked concept of psukhe that equates with the principle of life, giving it the capacity for 'self-nourishment, growth and decay' (Aristotle, De Anima 2.1.412a15). Along with the notion of the universal principle of life, he also introduces $z o \bar{e}$ (biological, vegetative life) and bios (the 'good' life of citizens). These concepts play an important role in both Agamben's (1998) account of biopolitics and Rosi Braidotti's (2006) politics of life itself. As Thacker (2010: 13) emphasises, any ontology of life that follows Aristotle's path has to formulate what is the basic 
principle of life. It needs to set 'boundaries of articulation' (categories through which the living may be distinguished from the non-living) and 'governing motifs' (the logical terms that order the analysis of life).

But within philosophy there are also other ways of investigating ontology of life. Thacker suggests that in the post-Kantian tradition it becomes clear it is precisely because humans are living beings (the subjects of life) that they are able to think about the life of other beings and their own (life as an object). In other words, there is no division between (unreachable by human thought) life-in-itself and the living. Instead, there is 'an immanent life, omnipresent and universally affirmative' (2010:13). Such an affirmative take on life as immanent flux can be found in different forms in German idealism, phenomenology and process ontologies (cf. Thacker 2015).

The question of the division between life and the thought of life is also present in the work of French physician and philosopher, Georges Canguilhem, whose theories of epistemology and life had a substantial impact on both Michel Foucault and Gilles Deleuze. Canguilhem argues that there is no discrepancy, gap, or hierarchy between knowledge and life. Rather, knowledge (the thought of life) is the product of life, it is a form of life and 'a general method for the direct or indirect resolution of tensions between man and milieu' (Canguilhem 2008: xviii), or, in other words, a 'capacity to solve problems in new and creative ways' (Marrati and Meyers 2008: xi). Life (human and nonhuman) is not an irrational or 'blind and stupid mechanical force' (Canguilhem 2008: xviii). Nonhuman life is not inferior to the human variety. They are different and they generate different kinds of knowledge. Canguilhem underlines the importance of both the internal and external milieus of the organism: 'the organism's adaptation to its milieu is attributed to the initiative of the organism's needs, efforts, and continual reactions. The milieu provokes the organism to orient its becoming by itself' $(2008: 115){ }^{3}$ 
The relation between organisms and their milieu (as crucial for the transformation and communication of organisms) also forms part of Deleuze and Félix Guattari's theorisations of life, ontology and ethics. While drawing on such thinkers as Baruch Spinoza ('ethics of affects'), Henri Bergson ('duration' and élan vital), Friedrich Nietzsche ('eternal return') and Gilbert Simondon ('individuation'), among others, Deleuze and Guattari understand life as that which 'runs between them [the organic and the inorganic], an impersonal force of contraction and dilation that characterizes events, even non-living events, as much as it does life' (Grosz 2011: 27). In this way, life is not a property that pertains to an individual. Instead, it is an impetus, of which an entity might be an expression. Life is not opposed to matter, nor does it have a transcendent source. Rather, it is 'the elaboration and expansion of matter, the force of concentration, winding or folding up that matter unwinds or unfolds' (2011:31).

Such a theorisation of life is built upon a non-dialectical understanding of difference (difference that is not based on identity, but is understood as a process), a dynamic idea of matter and duration (a non-quantified flow of time experienced in its immediacy), and the concept of becoming (open-ended processuality, ongoing transformations). Deleuze and Guattari (2004) emphasise the crucial character of connections and processuality. It is this interconnectivity that influences the ways organisms or entities materialise and transform. Becoming precedes the subject and the organism: 'Rather than a product, final or interim, becoming is the very dynamism of change, situated between heterogeneous terms and tending towards no particular goal or end-state' (Stagoll 2010: 26).

An understanding of life inspired by different process philosophies: life as a material force, processuality enacted through connections and intra-actions, and 'radically immanent'4 becoming, forms part of contemporary continental feminist theory. It is present in Braidotti's (2006) concept of zoe, Claire Colebrook's (2010) 'passive vitalism', and Patricia MacCormack's (2012) 'ahuman ethics'. I am bringing these concepts here as they constitute a 
theoretical ground in which the present argument is anchored. They all explore forces and intensities that take life beyond itself, beyond the containment of established boundaries and relations. And finally, they are all attentive to the enmeshment of nature/culture, living/nonliving and biomatter/technology.

While looking at the unfolding of TC\&A's bioart projects and the involved procedures through such a theoretical lens, we may see that these bioartistic practices mobilise a particular understanding of life. They expose life as the non/living. The concept of the non/living addresses the question of locating the constitutive characteristics of life prominent in both biological and philosophical enquiries. In particular, I am thinking here about two problems: what counts as life and how we account for life forms that do not fulfil the four basic criteria of the living (the entity has a body; it metabolises; it reproduces; and it is capable of movement) commonly referred to in bioscience. For instance, viruses prove that the criterion of reproduction (and passing on hereditary information) is not necessarily valid since, in order to replicate, viruses need a host cell. The non/living accounts for the complexity of the relationship between living and dying (and the living and the non-living) - the tissues in $V L$ are an acute expression of the concept. The death of individual cells and fragments of tissue overlaps with the growth of contaminants: life functions and the materiality of the tissues become resources for the infecting organisms. It is these tissues that serve as food, dwelling, and support system for the fungi, bacteria, and viruses that contaminate them. Life and death are not separate realms or fixed points. Instead, living and dying are processes: material forces that unfold, intertwine, and express themselves in what we evaluate as life and death. The slash ( $/ 9)^{5}$ in the term non/living emphasises this entwinement and the processual dynamics at work: the living and non-living are not a binary opposition, but are intra-active and enmeshed with one another.

Along with the contestation of a distinction between life and death, bioartworks undermine individualism and anthropocentrism that pervades Western cultural imaginaries. In the context 
of $V L$, it becomes clear that life is not a defining attribute of distinct entities, but instead, a set of processes through which entities emerge and are shaped. Bioartworks demonstrate that the non/living may be better thought through the concept of 'assemblage', which refers to a multiplicity of different components, the characteristics of which are constituted, shaped, and transformed only through their connections with other elements within and outside of the assemblage. Multiplicities express the capacity to organise themselves, modulate, and dismantle. Connections and interactions transform the properties of both the involved multiplicities and their components. As Deleuze and Guattari write, 'a multiplicity is continually transforming itself into a string of other multiplicities, according to its thresholds and doors' (2004: 275). The tissue of $V L$ as a multiplicity of cells - each of which is itself an assemblage of organelles and molecules - interacts with the contaminant: the collective of fungal cells, which may not only alter the appearance and behaviour of the tissue, but also interfere with its cell functions, such as metabolism, growth, the structure of membranes, and chromosomes. 'Reaching its threshold' for the tissue of $V L$ means that its cells can no longer perform their functions in the same way: their capacities to grow, metabolise, and multiply are altered by the growth and metabolism of the fungi. Each component of the assemblage carries its own potentials that unfold and actualise in their encounters with other components, forces, and multiplicities.

Furthermore, assemblages are also characterised by lines of 'deterritorialisation'. That is, a capacity for change, modification, and the undoing of present connections. Deleuze and Guattari's (2004) concept of deterritorialisation refers to forces and intensities that take life beyond itself, beyond the containment of established boundaries and relations. If deterritorialisation describes the ways in which forces traverse and transgress boundaries, limitations, thresholds, and containment, then we can say that deterritorialisation expresses itself in excess. It is this potential for excess that renders non/living assemblages uncontainable. 


\section{Conclusion: Uncontainability, Ethics and Monstrous Futures}

$V L$ - an art project that holds its own position in the contemporary cultural imaginary - exposes key aspects of the ontology of life: (1) the processual entwinement of the living and non-living, organic and inorganic, growth and decay, and ultimately, life and death; (2) the non/living is always already multiplicitous; and (3) it carries a potential for excess and thus transgresses both material and conceptual boundaries. Such a reformulation of ontology, anchored in feminist and process philosophies, and thought through the hybrid practices of bioart, challenges the conventional understanding of life (as pertaining to contained bodies), the body (as sealed) and the subject (as autonomous). It also brings to light difference as a dynamic, processual transformation. Not as something opposed to an identity in dialectical terms, but instead, as an ongoing process of differing/becoming. Such an ontology of life evokes and revitalises all Aristotelian characteristics of monstrosity: it manifests excess (transgressing bodily boundaries), deficiency (expressing itself in that which does not fulfill the conventional criteria of 'life') and displacement (through its entwinement with death). In other words, thinking with bioartworks demonstrates that the monstrous lays at the very heart of the ontology of life. We cannot escape the monstrous as we cannot escape the non/living; instead, we may and should learn anew how to relate to it.

The question of ethics concerns relationality. Ethics does not equate with morals. Deleuze brings this aspect of Spinoza's thought to the forefront: for Spinoza 'Ethics, which is to say, a typology of immanent modes of existence, replaces Morality, which always refers existence to transcendent values ... Morality is the system of Judgement' (Deleuze 1988: 23). In this way, ethics focuses on relationalities between different elements. It asks whether the encounters and relations into which the body enters are compatible with this body and increase its power (in which case they are considered good) or, conversely, whether they diminish and decompose this body's power (and, thus, are considered bad). The opposition of moral values (Good-Evil) 
is replaced with 'the qualitative difference of modes of existence (good-bad)' (23). In other words, ethics does not rely on a reference to an external principle or code, instead, its perspective is 'relative and partial' (22). This concern with relations and their specificity as the primary focus of ethics can be found not only in Deleuzian-Spinozian theorising, it is shared by many feminist materialist and postconventional theorists: Barad's ethico-onto-epistemology (2007), Margrit Shildrick's ethics of risk (2002) and Jacques Derrida's ethics of hospitality (Dufourmantelle and Derrida 2000), among others. Ethics, in their postconventional understandings, do not provide us with fixed recipes and ultimate answers on how to approach the non/living, how to relate to the human and nonhuman, or how to act well. Ethics are not sets of given principles, but instead, emerge from within and are shaped through particular assemblages, encounters and situations. Consequently, art's ethical potential does not consist in giving us moral guidelines or final answers. Instead, art affects us in the ways that interfere in and change our perceptions, and, subsequently, modify the relations among different components of the assemblage (the audience, the artwork, and their context). ${ }^{6}$

Against this background, what do the non/living artworks, like $V L$, tell us about ethics? What kind of promise do they give? As Joanna Zylinska emphasises, ethics should be 'premised on a long-term nonnormative commitment to understanding the production and emergence of what we call "life" in its multiple materializations, mediations, and symbolizations" (2009: 179). In other words, ethics that refers to life is closely entwined with life's ontology. As TC\&A's artworks demonstrate, the non/living (that the human and nonhuman form part of) is monstrous, vulnerable and uncontainable at its very ontological core. It requires an attentive approach to ever-changing difference, which should be simultaneously complex, particular and expressed on a case-by-case basis. We cannot fully control, discipline or predict what the non/living does and how it unfolds. 
While TC\&A's projects clearly express a critique of the illusion of control over life in connection to biotechnology, this critique deserves a broader recognition and reflection. In the times of the so-called Anthropocene, the sixth great extinction and irreversible global changes in biodiversity and the environment at large, caused by human activity, the cultural imaginaries feed us with dystopian visions popularised through films, fiction and computer games, on the one hand, and with optimism and uncritical belief in the omnipotence of technoscientific progress and human mastery over nature, on the other. Thinking with the non/living of bioartworks offers a more modest, yet careful approach: while attending to difference and indeterminacy, we shall take responsibility for and towards the relations we enter. Although, as Derrida emphasises, infinite responsibility constitutes an 'impossible horizon', we need to strive to make responsible decisions that are 'to be re-evaluated at each moment, according to concrete situations' (2001: 56). By exposing life as uncontainable, TC\&A's bioartworks catalyse situations and encounters that force us to ask ourselves how such forms of the non/living alter our perceptions; how we relate to them; and finally, what kind of responsibility we take in these particular instances. None of the answers are given in advance. As Derrida writes, 'A future that would not be monstrous would not be a future; it would already be a predictable, calculable and programmable tomorrow. All experience open to the future is prepared or prepares itself to welcome the monstrous arrivant' (1995: 286-7).

\section{References}

Agamben, Giorgio (1998), Homo Sacer: Sovereign Power and Bare Life, translated by Daniel Heller-Roazen, Stanford: Stanford University Press.

Aristotle (2011), De Anima, translated by Mark Shiffman, Newsburyport, MA: Focus Publishing.

The Art Catalyst (2012), Oron Catts Naked Matter March 2012, March, https://vimeo.com/40582752 
Barad, Karen (2007), Meeting the Universe Halfway: Quantum Physics and the Entanglement of Matter and Meaning, Durham: Duke University Press.

Braidotti, Rosi (2006), Transpositions, Cambridge: Polity.

Canguilhem, Georges (2008), Knowledge of Life, edited by Stefanos Geroulanos and Daniela Ginsburg, translated by Paola Marrati, Todd Meyers, New York: Fordham Unversity Press. Colebrook, Claire (2010), Deleuze and the Meaning of Life, New York: Continuum.

Colebrook, Claire (2014), Sex After Life, Ann Arbor: Open Humanities Press.

Deleuze, Gilles (1988), Spinoza: Practical Philosophy, translated by Robert Hurley, San Francisco: City Lights Books.

Deleuze, Gilles (2005), Pure Immanence: Essays on A Life, translated by Anne Boyman, New York: Zone Books.

Deleuze, Gilles and Félix Guattari (1994), What is Philosophy?, translated by Hugh Tomlinson and Graham Burchell, New York: Columbia University Press.

Deleuze, Gilles and Félix Guattari (2004), A Thousand Plateaus, translated by Brian Massumi, London: Continuum.

Derrida, Jacques (1995), Points ... Intervies 1974-1994, edited by Elisabeth Weber, translated by Peggy Kamuf, Stanford, CA: Stanford University Press.

Derrida, Jacques (2001), On Cosmopolitanism and Forgiveness, translated by Mark Dooley and Michael Hughes, London: Routledge.

Dufourmantelle, Anne and Jacques Derrida (2000), Of Hospitality, Stanford: Stanford University Press.

Foucault, Michel (2003), Abnormal:Lectures at Collège de France 1974-1975, translated by Graham Burchell, London: Verso.

Grosz, Elizabeth (2011), Becoming Undone: Darwinian Reflections on Life, Politics and Art, Durham: Duke University Press.

Haraway, Donna J. (2008), When the Species Meet, Minneapolis: University of Minnesota Press.

Johung, Jennifer (2014), 'The Vital Maintenance', Artlink: Cotemporary Art of Australia and Asia-Pacific, 34:3, pp. 46-49.

Juelskjær, Malou and Nete Schwennesen (2012), 'Intra-active Entanglements - An Interview with Karen Barad', Kvinder, Køn \& Forskning, 1-2, pp. 10-24.

Maastricht University (2015), Cultured Beef, http://culturedbeef.net/homepage/

MacCormack, Patricia (2012). Posthuman Ethics: Embodiment and Cultural Theory, Burlington: Ashgate. 
Marrati, Paola and Todd Meyers (2008), 'Forward: Life, as Such', in Georges Canguilhem, Knowledge of Life, New York: Fordham University Press, pp. vii-xii.

Martin, Bernice M. (1994), Tissue Culture Techniques: An Introduction, New York: Springer Science + Business Media LLC.

mediasanctuary (2014). Oron Catts 'Growing Neolifism', 17 April, http://youtu.be/9nu74yYQ34

Mehrabi, Tara (2016), Making Death Matter: A Feminist Technoscience Study of Alzheimer's Sciences in the Laboratory, Linköping: Linköping University Press.

Radomska, Marietta (2016), Uncontainable Life: A Biophilosophy of Bioart, Linköping: Linköping University Press.

Schwartz, John (2008), 'Museum Kills Live Exhibit', New York Times, 13 May.

Senior, Adele (2008), 'In the Face of the Victim: Confronting the Other in the Tissue Culture and Art Project', in Jens Hauser (ed.), Sk-interfaces: Exploding Borders - Creating Membranes in Art, Technology and Society, Liverpool: Fact \& Liverpool University Press, pp. 76-82.

Shildrick, Margrit (1997), Leaky Bodies and Boundaries: Feminism, Postmodernism and (Bio)ethics, London: Routledge.

Shildrick, Margirt (2002), Embodying the Monster: Encounters with the Vulnerable Self, London: Sage.

Shildrick, Margrit (2009), Dangerous Discourses of Disability, Subjectivity and Sexuality, London: Palgrave Macmillan.

Stagoll, Cliff (2010), 'Becoming', in Adrian Parr (ed.), The Deleuze Dictionary: Revised Edition, Edinburgh: Edinburgh University Press, pp. 25-27.

Stone, Maddie (2015), 'The Future Will Be Full of Lab Grown Meat', Gizmodo, 3 August, http://gizmodo.com/the-future-will-be-full-of-lab-grown-meat-1720874704

Sullivan, Nikki and Samantha Murray (2009), 'Introduction', in Nikki Sullivan and Samantha Murray (eds.), Somatechnics: Queering the Technologisation of Bodies, Surrey: Ashgate, pp. 1-12.

TC\&A (The Tissue Culture and Art Project) (2001), TC\&A, http://www.tca.uwa.edu.au/atGlance/galnceMainFrames.html Thacker, Eugene. (2010), After Life, Chicago: Chicago University Press.

Thacker, Eugene. (2015), Starry Speculative Corpse [Horror of Philosophy, vol. 2], Winchester, UK: Zero Books. 
Uexküll, Jakob von (2010), A Foray Into the Worlds of Animals and Humans: With a Theory of Meaning, translated by Joseph D. O’Neil, Minneapolis: University of Minnesota Press.

Wolfe, Cary (2012), Humans Before the Law: Humans and Other Animals in a Biopolitical Frame, Chicago: University of Chicago Press.

Ziarek, Ewa Plonowska (2012). 'Bare Life', in Henry Sussman (ed.), Impasses of the PostGlobal: Theory in the Era of Climate Change. Volume II, Ann Arbor: Open Humanities Press - University of Michigan Library, pp. 194-212).

Zurr, Ionat and Oron Catts (2003), 'The ethical claims of Bio Art: killing the other or selfcannibalism?' Australian and New Zealand Journal of Art: Art \& Ethics, 4:2, pp. 167-188. Zylinska, Joanna (2009), Bioethics in the Age of New Media, Cambridge: The MIT Press.

1. For a critical discussion on bioart's ethico-political potential, see Zylinska 2009.

2. The $3 \mathrm{~T} 3$ cell line originates from a Swiss albino mouse embryo. 3T3 cells are used in bioscientific research as an 'environment' and growth factor in the cultivation of other types of cells. The HaCat cell line was established from cells taken from a 62-year-old male patient with skin cancer (Senior 2008).

3. Cf. von Uexküll 2010.

4. Deleuze (2005) introduces the concept of 'radical immanence' in order to describe that which is not constituted and defined in reference to an outside, which is immanent only to itself, and characterised by becoming (processuality) rather than being (immutable presence).

5. As Barad explains in the context of her theory of agential realism, the potential of the slash lies in its 'indicating an active and reiterative (intra-active) rethinking of the binary' (Juelskjær and Schwennesen 2012: 19).

6. See for example: Deleuze and Guattari 1994; MacCormack 2012; and Colebrook 2014. 